\title{
MARYNA KAZHARNOVICH*
}

\section{Onomastická metafora ako lingvokultúrny fenomén ${ }^{1}$}

KAZHARNOVICH, M.: Onomastic metaphor as a linguacultural phenomenon. Slavica Slovaca, 56, 2021, No 1, pp. 17-25 (Bratislava).

The article examines the onomastic metaphor as a linguacultural unit, which is formed when using a proper name in the secondary nomination. The emergence of the onomastic metaphor is possible due to the broad connotative possibilities of the precedent onym. The article presents various approaches to the interpretation and terminological definition of the linguistic status of an onym in the secondary nomination: from appellation as a classical approach to understanding an onym with a connotative meaning, to perceiving it as a specific linguistic-cultural unit. The concept of an onomastic metaphor, which is formed on the basis of a precedent name that is cognitively relevant for representatives of a certain linguacultural space, is examined separately. The main features of a precedent name are highlighted, which allow it to form a metaphorical context. Onomastic metaphor is presented as a way of cognition, structuring and axiological interpretation of reality.

Onym, precedent name, connotation, onomastic metaphor, linguoculture.

\section{Úvod}

$\mathrm{V}$ jazykovede je dodnes spornou otázka lingvistického statusu vlastného mena $\mathrm{v}$ druhotnej nominácii. Definovanie takéhoto onyma ako onomastickej metafory je jednou z možných ciest vyriešenia danej lingvistickej diskusie. Vznik tohto druhu metafory je podmienený konotatívnym obsahom onyma, ktorý mu dovol'uje formovat' metaforicky kontext. Proprium, ktorého primárna funkcia je nominatívno-identifikačná, sa v onomastickej metafore stáva zdrojom mimojazykovej informácie, pomenúvajúc určité vlastnosti a zároveň hodnotiac novú entitu. Onomastická metafora predstavuje jeden zo spôsobov zachovania kultúrnej informácie. V komunikácii funguje ako národne špecifický kód, zachytáva výsledky kulturologicky významných skúseností človeka a národa, určuje systematickost' kultúry a stupeň jej rozvoja. Zmena priorít a hodnôt podnecuje aj zmenu spôsobov metaforizácie. Preto onomastická metafora umožňuje analýzu špecifík jazykového povedomia jedinca, ako aj lingvokultúrneho spoločenstva, čo je prioritou a ciel’om jazykovedného výskumu v rámci súčasnej vedeckej antropocentrickej paradigmy.

\section{Problém určenia lingvistického statusu onyma v druhotnej nominácii}

V súčasnej vedeckej literatúre sa stretávame s rôznymi prístupmi k problému lingvistického chápania a terminologického vymedzenia onyma $\mathrm{v}$ druhotnej nominácii. Pri rozdel’ovaní apelatívnej a propriálnej lexiky sa tradične akcentuje funkčný aspekt a zdôrazňuje sa, že sémantický protiklad apelatívum - proprium je funkčne podmienený. ${ }^{2}$ Pri onymickej nominácii

\footnotetext{
* Mgr. Maryna Kazharnovich, PhD. Filozofická fakulta Univerzity Komenského v Bratislave, Gondova 2,81102 Bratislava.

${ }^{1}$ Štúdia vznikla v rámci riešenia grantu MŠVVŠ SR VEGA 1/0111/20 Komunikačná kultúra v graduálne demokratizovanej spoločnosti a grantu Agentúry na podporu výskumu a vývoja na základe Zmluvy č. APVV-18-0176 Sociálna inklúzia kultiváciou používania jazyka.

${ }^{2}$ Blanár, V.: Teória vlastného mena (status, organizácia a fungovanie v spoločenskej komunikácii). Bratislava: Veda, 1996, s. 17.
} 
sa do popredia dostávajú funkcie identifikácie a individualizácie pomenovaného objektu. ${ }^{3}$ Hranica medzi apelatívnou a propriálnou lexikou sa však môže narúšat’ práve na funkčnej úrovni. V bežnej komunikácii sa napríklad vlastné mená ako Don Juan, Don Quijote, Eldorádo často používajú v nasledujúcich kontextoch: Clinton je len verným obrazom ich otca $W$. J. Blytha, ktorý bol známy ako vel'ký donchuan (Sme), Klaus už dlhé roky ako donkichot európskej politiky upozorňuje na hrozby dnešnej európskej unifikácie (Týždeň), Mexiko je Eldorádo pre cudzincov: je prekvapivo ústretové voči cudzincom (Sme). V týchto prípadoch onymá Don Juan, Don Quijote a Eldorádo nadobúdajú funkciu charakteristiky a hodnotenia nových reálií. Vd'aka svojej opakovatel'nosti sa tieto vlastné mená už vôbec nevnímajú ako mená konkrétnych osôb alebo v prípade toponyma Eldorádo - ako názov fiktívneho geografického objektu, ktorý sa zväčšia používa $\mathrm{v}$ apelativizovanom význame na pomenovanie vlastnosti. Preto sú často zaznamenané aj v slovníkoch rôznych jazykov, porovnaj „donchuan - zvodca žien, záletník, sukničkár“, ${ }^{4}$, „донжуан - шукальнік любоўных прыгод, спакуснік жанчын“,5 „донжуан -

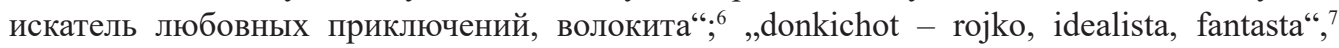
„донкіхот - фантазёр, які самааддана змагаецца за адцягненыя ідэалы дабра“,, „донкихот фантазер, наивный мечтатель, бескорыстно, но бесплодно борющийся за неосуществимые идеалы“; ; ,eldorádo - miesto radosti, hojnosti ap., raj“, ${ }^{10}$ „,краіна казачных багаццяў і цудаў; месца, дзе ў дастатку знаходзіцца што-н.““, ${ }^{11}$ „,страна неиссякаемых богатств и чудес“. ${ }^{2}$

Bežná komunikácia sa však neobmedzuje len na tieto dobre známe príklady. Onymá sa často používajú v druhotnej nominácii, realizujúc svoj konotatívny potenciál, napríklad Ako sa stat' novým Hendrixom ${ }^{13}$ (Sme), Pokial’ sa česká politická elita nezbaví sna ,o druhom Havlovi “ a o „niekom populárnom“, skonči to s inštitúciou hlavy štátu zle (NS), Svoj sólokoncert tu v rámci turné Spomínanie odohral český Elvis Presley Karel Zich (Sme), Šaron by rád videl budúcnost' palestínskeho štátu $v$ malých separovaných oblastiach, ktoré by sa dostali pod kontrolu miestnych velitel'ov. Toto, samozrejme, zaváňa budúcim Afganistanom (NS), Prečo Slovensko nesmie byt' východoeurópskym Detroitom? (Sme). V týchto kontextoch propriá rozširujú svoj informačný obsah, ked’že v sebe spájajú funkciu onymickej nominácie s funkciou axiologického hodnotenia novej skutočnosti. Vystáva tu však otázka lingvistického definovania onyma v druhotnej nominácii. Čerpajúc z aktuálneho stavu poznatkov, súčasná veda neponúka jednotný názor na tento problém.

Onymá v uvedených kontextoch sú tradične považované za príklady apelativizácie proprií. Existuje všeobecne prijímaný názor, že vlastné mená prechádzajú do kategórie apelatív, ked’

\footnotetext{
${ }^{3}$ Bližšie pozri Gardiner, A.: Theory of proper Names. A Controversial Essay. London - New York - Toronto: Oxford University Press, 1954, s. 73; Šrámek, R.: Paradigma onomastiky. In: Jazykovědné aktuality, 1994, roč. 31, č. 1, s. 20; Mistrík, J.: Lingvistický slovník. Bratislava: SPN, 2002, s. 240.

${ }^{4}$ Kačala, J. - Pisárčiková, M. - Považaj, M. (red.): Krátky slovník slovenského jazyka. Bratislava: Veda, 2003.985 s. Dostupné na: https://slovnik.juls.savba.sk/

${ }_{5}^{5}$ Суднік, М. Р. - Крыўко, М. Н. (рэд.): Тлумачальны слоўнік беларускай літаратурнай мовы. Мінск: БелЭн, 2002.

784 c. Dostupné na: http://www.slounik.org/

${ }^{6}$ Кузнецов, С. А. (ред.): Большой толковый словарь русского языка. Санкт-Петербург: Норинт, 1998.1534 с. Dostupné na: http://gramota.ru/slovari/info/bts/

${ }^{7}$ Krátky slovník slovenského jazyka, c. d.

8 Тлумачальны слоўнік беларускай літаратурнай мовы, c. d.

${ }^{9}$ Большой толковый словарь русского языка, c. d.

${ }^{10}$ Krátky slovník slovenského jazyka, c. d.

11 Тлумачальны слоўнік беларускай літаратурнай мовы, с. d.

12 Большой толковый словарь русского языка, c. d.

${ }^{13}$ Jimi Hendrix (1942-1970) - americký gitarista-virtuóz, spevák a skladatel'.
} 
„slúžia na pomenovanie triedy rovnorodých predmetov a javov“. ${ }^{14}$ Určujú sa aj rôzne kritériá (morfologické, slovotvorné, syntagmatické atd'.) apelativizácie proprií. ${ }^{15}$ Obyčajne sa na ilustráciu prípadov apelativizácie vlastných mien uvádzajú všeobecne známe príklady, ktoré sa často vyskytujú v komunikácii, a niektoré z nich sú už aj lexikograficky spracované. Bežná komunikácia však na analýzu poskytuje ovel'a väčšie množstvo oným v druhotnej nominácii.

Lingvisti, ktorí za obligatórny znak vlastného mena pokladajú monorefenčnost', t. j. pomenovanie jedinečného objektu, odmietajú možnost' prechodu proprií k apelatívam, aspoň na úrovni synchrónneho skúmania, odvolávajúc sa pritom na skutočnost’, že,,vlastné mená nedisponujú klasifikačným a charakterizačným významom“. ${ }^{16} \mathrm{Na}$ základe uvedeného prístupu sa potom onymá v druhotnej nominácii považujú za apelatíva, ktoré sú synonymické s propriálnymi jednotkami.

V rétorike sa spôsob pomenovania l'udských vlastností pomocou vlastného mena považuje za zvláštny výrazový prostriedok - antonomáziu ako opisné pomenovanie. ${ }^{17}$ Niekedy sa o antonomázii hovorí ako o hybride parafrázy a metafory alebo parafrázy, metafory a metonymie. ${ }^{18}$ V niektorých prácach sa vlastné meno s takýmto obrazným významom hodnotí ako typ alúzie, ktorý predpokladá usúvzt'ažnenie analyzovanej entity s ustáleným literárnym, historickým alebo mytologickým pojmom. ${ }^{19}$ Rétorika teda skúma vlastné meno v druhotnej nominácii ako jeden z trópov. Daný prístup redukuje funkciu onyma v metaforickom kontexte na funkciu obyčajného výrazového prostriedku. Opomína jeho poznávacie možnosti, ktoré nám umožňujú skúmat' ho z pozície spôsobu spracovania a zachovania informácí́.

Zástancovia koncepcie intertextuálnosti definujú vlastné meno v druhotnej nominácii ako intertextému - jednotku, ktorá je formálnym ukazovatel'om intertextuálnosti. ${ }^{20}$ Bieloruský lingvista A. E. Suprun zarad'uje onomastické jednotky, ktoré majú literárny pôvod (poetonymá), do kategórie textových reminiscencií spolu s citátmi, obraznými výrazmi, priamymi a nepriamymi odkazmi na rôzne situácie a ich účastníkov: „textové reminiscencie sú uvedomelé alebo neuvedomelé, presné alebo modifikované citáty a iné odkazy na viac-menej známe, skôr vytvorené texty v rámci neskôr vytvoreného textu“. ${ }^{21}$ Takýto prístup k skúmaniu onyma v druhotnej nominácii sa obyčajne obmedzuje len na skúmanie poetoným.

V súčasnej odbornej a vedeckej literatúre sa vo vzt'ahu k onymu v druhotnej nominácii používa aj termín logoepistéma, ktorý navrhli ruskí lingvisti V. G. Kostomarov a N. D. Burviková. Logoepistéma (gréc. logos - 'slovo', episteme - 'znalosti') je ,jazykové uchopenie odrazu skutočnosti, ktorý je zafixovaný kultúrnou pamät'ou v povedomí nositel’ov jazyka ako výsledok

\footnotetext{
${ }^{14}$ Виноградов, В. В. (ред.): Грамматика русского языка. Фонетика и морфология. Москва: Издательство АН CCCP, 1952, c. 104.

${ }^{15}$ Blanár, V.: Teória vlastného mena, c. d., s. 159.

${ }^{16}$ Dalberg, V.: On Homonymy between Proper name and Appellative. In Names. Journal of the American Name Society, 1985 , roč. 33, č. 3, s. 132 .

${ }^{17}$ Mistrík, J.: Rétorika. Bratislava: Slovenské pedagogické nakladatel'stvo, 1978, s. 105.

${ }^{18}$ Хазагеров, Т. Г. - Ширина, Л. С.: Общая риторика: курс лекций. Ростов-на-Дону: Феникс, 1999, с. $208-209$.

${ }^{19}$ Bližšie pozri Арнольд, И. В.: Читательское восприятие интертекстуальности и герменевтика. In Климович, И. А. (ed.): Интертекстуальные связи в художественном тексте. Санкт-Петербург: Образование, 1993, с. 4-12; Гюббенет, И. В.: Основы филологической интерпретации литературно-художественного текста. Москва: Издательство МГУ, 1991. 205 с.; Горнакова, Л. Ю.: Роль аллюзивного антропонима в семантике художественного текста. In: Известия высших учебных заведений. Серия “Гуманитарные науки”, 2010, № 1, с. 62-66.

${ }^{20}$ Bližšie pozri Мокиенко, В. М.: Интертекстемы и тескт в славянских языках. In Шулежкова, С. Г. (ed.): Интертекст в художественном и публицистическом дискурсе. Магнитогорск: Магнитогорский гос. ун-т, 2003, c. 4-27; Фатеева, Н. А.: Типология интертекстуальных элементов и связей в художественной речи. In: Известия РАН. Серия литературы и языка, 1998, том 57, № 5, с. 24-38.

${ }^{21}$ Супрун, А. Е.: Текстовые реминисценции как языковое явление. In: Вопросы языкознания, 1995, № 6, с. 17.
} 
poznania (alebo vytvárania) duchovných hodnôt“.22 Logoepistéma je lingvokulturologická jednotka, ktorá nám dovol'uje vidiet' nový obsah cez prizmu národne špecifického jazykového obrazu sveta. Za logoepistémy sa považujú citáty, aforizmy, frazémy, príslovia, „hovoriace mená“ z literárnych diel, piesní a slovných prejavov známych osôb.

Vo vzt’ahu k onymu v druhotnej nominácii sa používa aj termín lingvokulturéma, ktorý navrhol ruský lingvista V. V. Vorobjov ${ }^{23}$ na označenie základnej opisnej jednotky lingvokulturológie, ktorá v sebe kumuluje kultúrne podmienenú extralingvistickú informáciu. Treba však dodat', že termíny logoepistéma a lingvokulturéma sú všeobecné lingvokulturologické pojmy, ktoré sa používajú vo vzt'ahu k jazykovým jednotkám ako nositel’om kultúrnej informácie a nevystihujú lingvistickú povahu onyma $v$ druhotnej nominácii.

Propriá sa v druhotnej nominácii skúmajú aj v rámci teórie precedentnosti. ${ }^{24}$ Precedentné onymum je osobitný jazykový znak, pri ktorého používaní hovoriaci neapeluje na denotát, ale na súhrn diferenciálnych vlastností určitého precedentného mena. ${ }^{25}$ Ruská vedkyňa O. N. Dolozovová vyčleňuje nasledujúce zložky v sémantickej štruktúre precedentného mena: 1) prvotný referent (R1) alebo prototyp (predmet pomenovaný menom);2) denotát(D), extencionál - predstava o referente, teda obraz, ktorý toto meno vyvoláva v podvedomí hovoriacich mimo kontextu; 3) signifikát (S), intencionál - pojem alebo komplex diferenciálnych príznakov, ktoré sú zafixované za denotátom; 4) druhotný referent (R2) - X, má príznaky, ktoré zahŕňa pojem S. ${ }^{26}$ Túto sémantickú štruktúru precedentného mena možno aplikovat’ na vlastné meno v druhotnej nominácii, ale treba dodat', že nie každé precedentné meno sa v komunikácii spája s druhotným referentom, t. j. nie každé precedentné meno realizuje svoj konotatívny potenciál. Preto ruský lingvista D. B. Gudkov rozlišuje denotatívne (intencionálne) a konotatívne (extencionálne) použitie precedentného onyma. ${ }^{27}$ Slovenský jazykovedec J. Sipko skúma onymum v druhotnej nominácii ako precedentné meno vo funkcii hodnotiaceho prostriedku. ${ }^{28}$

Niektorí lingvisti hovoria o pohyblivosti hranice medzi propriami a apelatívami. Napríklad ukrajinský jazykovedec A. A. Belecký zdôrazňuje, že v slovnej zásobe každého jazyka sú intermediárne lexikálne jednotky, ktoré majú v lexikálnom systéme prechodné postavenie. ${ }^{29}$ Takéto mená môžu v komunikácii fungovat' ako apelatíva alebo propriá, pričom sa ich konkrétny význam určuje v závislosti od kontextu. ${ }^{30}$

Ruskí jazykovedci M. J. Bloch a T. N. Semjonovová vyčleňujú aj osobitnú onomastickú jednotku - polantroponymum. ${ }^{31}$ Vznik a fungovanie polantroponyma sú podmienené špecifikom jeho jazykovej a rečovej sémantiky. Ide najmä o to, že z pragmatického hl'adiska sa sémantika

\footnotetext{
22 Костомаров, В. Г. - Бурвикова, Н. Д.: Старые мехи и молодое вино. Из наблюдений над русским словоупотреблением конца ХХ века. Санкт-Петербург: Златоуст, 2001, с. 39.

${ }^{23}$ Воробьев, В. В.: Лингвокультурология. Теория и методы. Москва: Издательство РУДН, 1997. 331 с.

${ }^{24}$ Bližšie pozri Караулов, Ю. Н.: Русский язык и языковая личность. Москва: Наука, 1987. 363 с.; Красных, В. В.: Этнопсихолингвистика и лингвокультурология: Курс лекций. Москва: ИТДГК „Гнозис“, 2002. 284 с.; Sipko, J.: Teoretické a sociálno-komunikačné východiská lingvokulturológie. Prešov: FF PU, 2011. $320 \mathrm{~s}$.

${ }^{25}$ Караулов, Ю. Н.: Русский язык и языковая личность, с. d., с. 30.

${ }^{26}$ Долозова, О. Н.: О семантике прецедентного имени, 2004. Dostupné na: www.philol.msu.ru/ rlc2004/ru/participants/psearch.php?pid=97225.

${ }^{27}$ Гудков, Д. Б.: Теория и практика межкультурной коммуникации. Москва: ИТДК „Гнозис“, 2003 , с. 154.

${ }^{28} \mathrm{Sipko,} \mathrm{J.:} \mathrm{Прецедентные} \mathrm{имена} \mathrm{в} \mathrm{позиции} \mathrm{оценочных} \mathrm{средств.} \mathrm{Prešov:} \mathrm{FF} \mathrm{PU,} \mathrm{2013.} 265$ s.

${ }^{29}$ Белецкий, А. А.: Лексикология и теория языкознания (ономастика). Киев: Издательство Киевского университета им. Т. Г. Шевченко, 1972. 209 с.

${ }^{30}$ Суперанская, А. В.: Имя и эпоха. In Суперанская, А. В. (еd.): Историческая ономастика. Москва: Наука, 1977, с. 7-27.

${ }^{31}$ Bližšie pozri Блох, М. Я. - Семёнова, Т. Н.: Имена личные в парадигматике, синтагматике и прагматике. Москва: Готика, 2001. 196 с.; Семёнова, Т. Н.: Антропонимическая индивидуализация: диалектика целого и части. In: Соловьев, В. Д. - Баранов, В. А. (еd.): Язык, литература и культура на рубеже XX-XXI веков. Уфа, 2008, с. 101-119.
} 
obyčajných antroponým vyznačuje sociálnou podmienenost'ou. Každé antroponymum disponuje všeobecnými jazykovými sémami, ku ktorým patria základné a fakultatívne, sociálne podmienené (sociálne a národno-etnické) charakteristiky. $\mathrm{Na}$ úrovni reči sa $\mathrm{k}$ základným komponentom významu pripájajú dodatočné, unikátne, individuálne vlastnosti antroponým - idiolektové sémy dvoch druhov: a) ustálené (stereotypne determinované), ktoré prezentujú typickú, ustálenú predstavu o nositel'ovi mena; b) meniace sa (predikatívne), ktoré prezentujú situačne podmienené predstavy hovoriaceho o nositel'ovi mena. Bola sformulovaná teória „opozičnej zámeny“, t.j prechod antroponým v určitých kontextoch k polantroponymám alebo bifunkčným jazykovým jednotkám, ktoré disponujú zmiešanými lexikálno-gramatickými vlastnost’ami. Takéto antroponymá okrem nominatívnej funkcie priberajú ešte aj dodatočnú funkciu hodnotenia reálií.

Ukrajinský lingvista E. S. Otin skúma propriá v analogických kontextoch ako konotatívne onymá - konotonymá, ktoré okrem základnej funkcie individualizácie a identifikácie objektov, sa vd’aka druhotným, sociálne dôležitým spoluvýznamom (konotémam) niekedy používajú v jazyku a reči ako ekvivalenty apelatívnych jednotiek. ${ }^{32}$ To znamená, že vlastné meno, ktoré pôvodne plní individualizačnú a identifikačnú funkciu, sa v určitých kontextoch stáva zdrojom mimojazykovej informácie a nadobúda konotačný obsah.

Treba však konštatovat', že terminologické prirovnávanie onyma v druhotnej nominácii k precedentnému menu, polantroponymu alebo konotonymu neodráža špecifikum jeho štruktúry. Takéto meno nefunguje totiž v komunikácii ako izolovaná jednotka s určitým konotatívnym obsahom, ale sa usúvzt'ažňuje s novým referentom, pričom ho charakterizuje a hodnotí.

Niektorí lingvisti hovoria o tom, že termín konotonymum je spojený so systémovou úrovňou (poukazuje na charakterizačný potenciál onyma) a termín metafora je spojený $\mathrm{s}$ úrovňou fungovania onyma. ${ }^{33} \mathrm{~V}$ posledných rokoch vyšiel celý rad publikácií, kde sa onymum v druhotnej nominácii hodnotí ako osobitný druh metafory. ${ }^{34}$ Prikláňame sa k názoru, že je naozaj nutné hovorit' o existencii takej jazykovej jednotky ako onomastická metafora, o čom svedčia štruktúrne a funkčné charakteristiky onyma v druhotnej nominácii. Metafora je jazyková jednotka, ktorá sa formuje na základe ,rozšírenia sémantického obsahu slova pomocou vzniku prenesených významov, založených na podobnosti““. ${ }^{35} \mathrm{~V}$ takomto prípade sa dá hovorit' o onomastickej metafore ako o jazykovej jednotke, založenej na rozšírení sémantického obsahu onyma vd'aka vzniku prenesených významov. Vlastné meno je schopné formovat' metaforický kontext za pomoci asociácií, ktoré sú zafixované v povedomí hovoriacich za jeho prvotným referentom. Pri používaní mena v druhotnej nominácii, ako aj pri konštruovaní metafory, sa uskutočňuje fiktívna klasifikácia - fiktívna ekvivalencia príslušných entít. ${ }^{36}$ Niektorí lingvisti odmietajú hovorit' o onyme v druhotnej nominácii ako o metafore odôvodňujúc to tým, že v tomto

\footnotetext{
32 Отин, Е. С.: Материалы к коннотационному словарю русских онимов. In Рут, М. Э. (ed.): Номинация в ономастике: сборник научных трудов. Свердловск: Прогресс, 1990, с. 40.

${ }_{33}^{3}$ Ратникова, И. Э.: Имя собственное: от культурной семантики к языковой. Минск: БГУ, 2003, с. 60.

${ }^{34}$ Bližšie pozri Воякина, Е. Ю.: Ономастическая метафора как одна из составляющих экономического лексикона. In Филологические науки. Вопросы теории и практики, 2009, № 2, с. 87-89; Калугина, Ю. Е.: О некоторых особенностях процесса метафоризации в экономической терминологии. In Вестник МГОУ, 2009, № 2, с. 29-34; Ларина, Т. И.: Особенности функционирования ономастических тропов в русско-, польско- и англоязычной публицистике. In Истомин, В. С. (ed.): Лингвокультурологическая парадигма в современных исследованиях. Сборник научных статей ГрГу им. Я. Купалы. Гродно: ГрГу, 2011, с. 274-279.

${ }_{35}^{35}$ Міхневіч, А. Я. (рэд.): Беларуская мова: энцыклапедыя. Мінск: БелЭн, 1994, с. 344.

${ }^{36}$ Dolník, J.: Jazyk a hodnotenie. Banská Bystrica: Univerzita Mateja Bela, 1999, s. 57; Dolník, J.: Lexikológia. Bratislava: Univerzita Komenského, 2007, s. 64.
} 
prípade sa uskutočňuje „pseudoidentifikácia v rámci jednej triedy, ktorá nevytvára metaforu““.37 Tu je však nutné pripomenút' si špecifikum onymickej nominácie, ktorá predpokladá, že každý onymický objekt je jedinečný, unikátny, a preto platí, že ,vlastné meno nie je len značkou, nálepkou svojho onymického objektu, ale predstavuje jeho osobitný príznak “. ${ }^{38}$ Možno teda len vel'mi zovšeobecnene konštatovat', že pri konštruovaní onomastickej metafory sa uskutočňuje usúvzt’ažnenie entít jednej triedy, ked'že ide o jedinečné objekty.

V odbornej a vedeckej literatúre existuje aj názor, ktorý popiera možnost' prechodu vlastného mena do novej jazykovej jednotky. Zástancovia tejto myšlienky hovoria o onyme v metaforickom kontexte len ako o jeho rečovej realizácii, ktorá je podmienená kontextuálne a pragmaticky. Ruský lingvista D. I. Jermolovič v sémantike vlastných mien vylučuje deskriptívny komponent, ktorý sa v komunikácii môže dostávat' do popredia v onymách, ktoré sú dobre známe v rámci určitého jazykového kolektívu. ${ }^{39}$ D. B. Gudkov zdôrazňuje, že tieto vlastné mená nemajú v klasifikačnej tabul'ke jazykových jednotiek osobitnú „,bunku“. Sú len skupinou v rámci propriálnej lexiky, ale predstavujú osobitné jednotky diskurzu. ${ }^{40}$

Uvedené prístupy $\mathrm{k}$ problému lingvistického chápania a terminologického vymedzenia onyma $\mathrm{v}$ druhotnej nominácii svedčia o komplikovanosti a nejednoznačnosti celej otázky. Ide o zvláštny prípad onymickej nominácie, ktorá predpokladá hodnotiace pomenovanie nových reálií. Zastávame názor, že vlastné meno v druhotnej nominácii formuje osobitý druh metafory, t. j. onomastickú metaforu.

\section{Lingvistická povaha onomastickej metafory}

Onomastická metafora je jazyková jednotka, ktorá sa formuje na základe metaforického použitia propria. V samotnom termíne onomastická metafora sa vyskytujú dva dôležité lingvistické pojmy: onymum a metafora. Preto, ked' hovoríme o lingvistickej povahe tejto jazykovej jednotky, hovoríme vlastne o podmienkach a spôsobe uskutočnenia procesu metaforizácie vlastného mena.

Konštruovanie onomastickej metafory je podmienené relatívne širokými nominatívnymi možnost’ami vlastných mien. Onymická lexika môže nielen pomenúvat' konkrétne jedinečné objekty a javy, ale môže sa používat' aj vo funkcii metaforickej nominácie. Je zrejmé, že nie každé vlastné meno realizuje v komunikácii svoj metaforický potenciál. Malo by íst' o také onymum, ktoré bude $\mathrm{v}$ podvedomí hovoriacich vyvolávat' určité asociácie, t. j. precedentné meno - všeobecne známe meno, ktoré je v kognitívnom pláne hovoriacich aktuálne a ktoré sa používa v komunikácii ako kultúrny znak, symbol určitých l'udských vlastností, charakteristík a spôsobov správania. V odbornej a vedeckej literatúre venovanej fenoménu precedentnosti sa určujú špecifické vlastnosti precedentných oným, ktoré ich charakterizujú a odlišujú od iných propriálnych jednotiek. ${ }^{41} \mathrm{~V}$ súvislosti s onomastickou metaforou nás budú zaujímat' tie vlastnosti precedentných mien, ktoré im dovol'ujú formovat' metaforický kontext.

Aktuálnost' v kognitívnom pláne. Precedentné onymum, na základe ktorého sa formuje onomastická metafora, je pre hovoriacich aktuálne $\mathrm{v}$ poznávacom a emocionálnom pláne.

\footnotetext{
${ }^{37}$ Арутюнова, Н. Д.: Теория метафоры. In Арутюнова, Н. Д. (еd.): Теория метафоры. Москва: Прогресс, 1990, s. 20.

${ }^{38}$ Blanár, V.: Teória vlastného mena, c. d., s. 23.

${ }^{39}$ Ермолович, Д. И.: Имена собственные на стыке языков и культур (заимствование и передача имён собственных с точки зрения лингвистики и теории перевода). Москва: Р. Валент, 2001. 200 с.

${ }^{40}$ Гудков, Д. Б.: Прецедентное имя и проблемы прецедентности. Москва: Издательство МГУ, 1999, с. 121.

41 Красных, В. В.: Этнопсихолингвистика и лингвокультурология, c. d.; Долозова, О. Н.: О семантике прецедентного имени, c. d.
} 
Takéto meno existuje v povedomí nositel'ov jazyka ako jednotka s určitým výsekom informácie, ktorý sa aktualizuje v procese poznávania skutočnosti. Napríklad význam onomastickej metafory Дамінік Татарка - славаџкі Валянцін Акудовіч ${ }^{42}$ (HН) bude pre príslušníkov bieloruského lingvokultúrneho spoločenstva celkom pochopitel'ný vd’aka ustálenej informácii, ktorú majú v povedomí fixovanú v spojitosti s nositel'om tohto mena: známy spisovatel', filozof, skúmatel' národného charakteru a mentality. V tomto prípade rovnako aj predstavitelia slovenského lingvokultúrneho spoločenstva môžu na základe mena Dominik Tatarka posudzovat' význam osobnosti Val'antina Akudoviča pre bieloruský kultúrno-spoločenský život, lebo pre nich je kultúrne a zároveň kognitívne príznakovým onymum Dominik Tatarka.

Nadindividuálna povaha. Možnost’ konštruovania a správneho dekódovania onomastickej metafory je podmienená nadindividuálnou povahou precedentného onyma, $\mathrm{v}$ ktorom je zafixovaná všeobecne známa informácia $\mathrm{v}$ rámci určitého lingvokultúrneho spoločenstva. Precedentné meno, na základe ktorého sa formuje onomastická metafora, predpokladá, že používatelia jazyka poznajú charakteristiky a vlastnosti fixované za jeho referentom. Napríklad onymum Adolf Hitler vyvoláva u hovoriacich jednoznačné asociácie spojené s osobnost'ou a tragickými následkami diktátorskej politiky tejto historickej postavy, porovnaj V Iraku vládne novodobý Hitler (Sme). Hovoriac o nadindividuálnej povahe onyma treba počítat' aj so stupňom jeho precedentnosti, čiže je dôležité rozlišovat' sociálno-precedentné, národnoprecedentné a univerzálno-precedentné mená.

Prototypovost'. Pri formovaní onomastickej metafory sa do popredia dostávajú typické charakteristiky, ktoré sa v podvedomí používatel’ov jazyka spájajú s prvotným referentom precedentného mena. Nová entita, na ktorú sa aplikuje precedentné onymum, má svoj prototyp v podobe prvotného nositel'a tohto mena. Onomastická metafora sa môže formovat' na základe prototypovej vlastnosti alebo prototypovej situácie, ktorá sa v podvedomí hovoriacich spája s nositel'om precedentného mena. Napríklad vo výpovedi Vroclavu sa niekedy hovorí pol'ské Benátky: centrum mesta leži na ramenách a kanáloch rieky Odry, je tu mnoho ostrovov a 117 mostov (Sme) sa metafora formuje na základe prototypovej vlastnosti - mesto, ktoré má množstvo vodných kanálov. A metafora Mad'arská vláda prevzala kontrolu nad hlinikárňou MAL, ktorá spôsobila takzvaný mad'arský Černobyl' (NS) je vystavaná na tragickej udalosti, spojenej s haváriou atómovej elektrárne.

Reprodukovatel'nost' a rozš́rené použitie v komunikácii. Vd’aka svojmu ustálenému informačnému obsahu sa precedentné onymum používa v komunikácii ako opakovatel'ná jazyková jednotka, ktorá v rámci onomastickej metafory umožňuje lakonickú a obraznú charakteristiku novej skutočnosti. Mnohé vlastné mená sa už vôbec nevnímajú ako pomenovania osôb, skôr ako pomenovania vlastností. Napríklad nie každý dnes vie, že Paparazzo je priezvisko dotieravého novinára z filmu Sladký život talianskeho režiséra F. Felliniho. Už takmer nikto nespája toponymum Eldorádo s bájnou juhoamerickou krajinou zo zlata a drahých kameňov. Pritom sa však tieto apelativizované onymá aktívne používajú v komunikácii v metaforických kontextoch, porovnaj Foto Šmotlák bol dobrotivý paparazzo, na ktorého prítomnost'sme si zvykli $v$ divadlách, na vernisážach a v televizii (Sme), A prečo sme eldorádom pre zahraničné banky, ktoré na našich l'ud'och zarábajú viac, ako na Západe? (NS).

Ustálenost'. Precedentné meno je v istom zmysle ustálená jednotka - má fixovaný konotatívny obsah, ktorý môže varírovat' v rámci onomastickej metafory. Napríklad za menom Che Guevara sú fixované nasledujúce charakteristiky: revolucionár, významný politický činitel', národný

${ }^{42}$ Doslovný preklad: Dominik Tatarka je slovenský Val’antin Akudovič. 
hrdina, bojovník za slobodu, modla svojej generácie. V rôznych metaforických kontextoch sa do popredia dostávajú aj rôzne konotatívne charakteristiky, ktoré recipient môže l'ahko odhalit' vd’aka ustálenému informačnému obsahu samotného precedentného mena, porovnaj Usáma (bin Ládin) zomrie ako hrdina so zbraňou v ruke, do posledného dychu a s poslednými vernými mužmi brániaci svojho boha kdesi v podzemných zadymených chodbách Tory Bory. Tak sa zrodí Che Guevara arabského sveta (DF), Barack Obama obsadil do klúčových pozícii republikánov <..> a ultrapragmatických $<_{\text {... }}$, teda l'ud'mi, ktorí, povedzme si to na rovinu, majú málo spoločné s tým, čomu v Európe hovoríme l'avica. Barack Obama nie je Che Guevara (Sme).

Jedinečnost'. Precedentné onymum je unikátna jednotka, konkrétne meno s prísne fixovaným konotatívnym obsahom. Táto jedinečnost' precedentného mena vylučuje dvojzmyselnost' pri odhal'ovaní významu onomastickej metafory a umožňuje porozumenie medzi producentom metafory a jej recipientom. Treba však spomenút' kultúrne podmienené možnosti modifikácie významového obsahu precedentného mena, ktoré sú niekedy spojené s rozdielnym chápaním a hodnotením tohto mena zo strany predstavitel’ov rôznych lingvokultúrnych spoločenstiev. Ruský jazykovedec J. A. Rylov upozorňuje na to, že to isté meno sa v rôznych kultúrach vníma inak. ${ }^{43}$ Napríklad priezvisko rodu Bourbon má rôzne konotácie v ruskom, talianskom a španielskom jazyku: v ruštine 'drsný, nekultúrny človek'; $v$ španielčine 'šikovný človek, ktorý vie vybavovat' veci, riešit' problémy'; $v$ taliančine sa toto precedentné meno používa v politickom kontexte na pomenovanie prívržencov reakčných metód, čo je spojené s politickým systémom v Neapolskom královstve počas vlády Bourbonovcov. To isté môžeme povedat' aj o mene starorímskeho verejného činitel'a Cicera: v ruštine 'človek, ktorý vie výrečne hovorit”; v španielčine 'sprievodca turistov' (tento sémantický význam mena Cicero vznikol vd’aka D. Alighierimu a úlohe sprievodcu, ktorú mal Cicero v jeho Božskej komédii); v taliančine 'človek, ktorý vel’a a zbytočne hovorí'.

Vlastnosti precedentného onyma, akými sú aktuálnost' v kognitívnom pláne, nadindividuálna povaha, prototypovost', reprodukovatel'nost', rozšírené použitie v komunikácii, ustálenost' a jedinečnost', mu dovol'ujú formovat' metaforický kontext. Ale nie každé precedentné meno realizuje v komunikácii svoj metaforický potenciál. Pri denotatívnom použití precedentné onymum, podobne ako každé iné vlastné meno, nominuje konkrétny objekt, napríklad Aktivisti environmentálnych organizácií pripomínajú slovenskej verejnosti, že podpisanie závažných dohôd o dostavbe prvých dvoch blokov Mochoviec sa deje desat' dní pred výročím jadrovej havárie v Černobyli (Sme). Toponymum Černobyl' tu pomenúva mesto, ktoré tragicky zasiahla havária jadrovej elektrárne. V prípade metaforického použitia sa v onyme Černobyl' výrazne aktualizuje séma 'vel'ká tragédia, katastrofa', porovnaj Druhý Černobyl' zrejme Japonsku nehrozi (HN). Občas sa však v komunikácii vyskytnú aj iné príklady vývoja sémantiky tohto precedentného toponyma, $\mathrm{v}$ ktorých vzniká nečakaný metaforický efekt, porovnaj Jednako až privel'a hrôzy naháňajú tvrdé metafory a katastrofické prirovnania, že ide už o ,,slovenský kultúrny Černobyl" "a minister kultúry Milan Kñažko má prichystanú lopatu a túži sa stat" „hrobárom a likvidátorom slovenskej literatúry“ (NS), Označit parižsky Disneyland za kultúrny Černobyl' si naozaj môže dovolit' len francúzska inteligencia (NS). V týchto príkladoch sa onymum Černobyl' aplikuje na iný denotát, ktorý nemá priame spojenie s miestom katastrofy.

Onomastická metafora je výsledok procesu metaforizácie precedentného onyma. V. N. Teliová zdôrazňuje, že metafora funguje ako „mechanizmus, ktorý predpokladá súčinnost' poznávacích procesov, empirických skúseností, kultúrnych výdobytkov kolektívu a jeho

${ }_{43}^{43}$ Рылов, Ю. А.: Имена собственные в европейских языках. Романская и русская антропонимика. Курс лекций по межкультурной коммуникации. Москва: АСТ: Восток - Запад, 2006, с. 296-297. 
jazykovej kompetencie, aby bolo možné v jazykovej podobe zachytit’ citovo vnímané objekty a zviditel'nit' neviditel'ný obraz sveta“. ${ }^{44}$ Metafora predpokladá interakciu medzi štruktúrami znalostí dvoch konceptuálnych domén: zdrojovej sféry (source domain) a ciel’ovej sféry (target domain). V dôsledku metaforickej projekcie (metaphorical mapping) zo zdrojovej do cielovej sféry modelujú elementy zdrojovej sféry menej známu ciel’ovú sféru. ${ }^{45} \mathrm{~V}$ prípade onomastickej metafory zdrojovú sféru predstavuje precedentné meno s celým radom typických vlastností, charakteristík a spôsobov správania, ktoré sú príznačné pre nositel’a tohto mena. Vo vzt’ahu k onomastickej metafore nejde len o metaforizáciu izolovaného onyma, ale celostnej konceptuálnej štruktúry s určitým kognitívnym kontextom, ktorý sa aktivizuje v povedomí hovoriacich.

Podl'a svojej lingvistickej povahy predstavuje onomastická metafora jazykovú jednotku, ktorá sa formuje na základe použitia precedentného onyma v metaforickej nominácii. Formovanie onomastickej metafory je podmienené konotatívnym významom vlastného mena, ktorý sa metaforicky prehodnocuje v komunikácii.

\title{
Záver
}

Onomastická metafora ako špeciálny druh metafory si zasluhuje osobitnú pozornost'. Ide o jazykovú jednotku, ktorá má nielen vlastný lingvistický, ale aj kulturologický význam. Jej konštruovanie je podmienené konotatívnym obsahom precedentného mena, na základe ktorého sa formuje metaforický kontext. Onomastická metafora ako účinný spôsob poznania a axiologickej interpretácie skutočnosti disponuje vel'kým pragmatickým a interdiskurzivným potenciálom.

\author{
Zoznam prameňov \\ Týždenník Domino fórum [DF] \\ Denník Hospodárske noviny [HN] \\ Internetový magazín Nové slovo [NS] \\ Denník Sme \\ Týždenník Tyžden̆ \\ Týždenník Нама Нiва $[\mathrm{HH}]$
}

\section{Ономастическая метафора как лингвокультурный феномен}

\author{
Марина Кажарнович
}

\begin{abstract}
В статье рассматривается ономастическая метафора как лингвокультурная единица, которая формируется при употреблении имени собственного во вторичной номинации. Возникновение ономастической метафоры обусловлено широкими коннотативными возможностями прецедентного онима. В статье представлены различные подходы к интерпретации и терминологическому определению лингвистического статуса онима во вторичной номинации: от аппелятивации как классического подхода к пониманию онима с коннатативным значением до осмысления его как специфической лингвокультурной единицы. Отдельно рассмотрена концепция ономастической метафоры, которая формируется на основе прецедентного имени, актуального в когнитивном плане для представителей определенного лингвокультурного пространства. Выделены основные признаки прецедентного имени, которые позволяют ему формировать метафорический контекст. Ономастическая метафора представлена как способ познания, структурирования и аксиологической интерпретации действительности.
\end{abstract}

44 Телия, В. Н.: Метафора как модель смыслопроизводства и её экспрессивно-оценочная функция. Москва: Наука, 1988, с. 180.

${ }^{45}$ Lakoff, G. - Johnson, M.: Metaphors we live by. Chicago: University of Chicago Press, 1980. 242 pp. 